\title{
PEMEROLEHAN FONOLOGI BAHASA INDONESIA ANAK LAKI-LAKI USIA 4 (EMPAT) TAHUN
}

\section{Riri Amanda Fitriana}

Sekolah Tinggi Kesehatan (STIKes) Har-Kausyar Rengat Riau, Indonesia

Email: ririamanda.fit@gmail.com

\section{Abstract}

This study aims to describe the acquisition of phonology in the form of acquisition of vowels, consonants, and diphthongs. The method in this research is a qualitative method with a case study approach obtained by a 4 year old man. In this study it was found that the IHA had acquired complete vowel phonemes at the age of 4 years and most consonant had also been obtained. He has also mastered the sound of double vowels or diphthongs. While the fricative sound [f], the vibrating sound [r] was not mastered until the age of 4 years. Uniquely, IHA has its own ola if it finds consonant $/ \mathrm{l} /$ and consonant $/ r /$ which is located at the end of a word. IHA will replace it with the phoneme // $\eta / /$. This happens because the speech motor that IHA has is incomplete or not yet fully developed.

Keywords: phonological acquisition; vocal; consonant;

\begin{abstract}
Abstrak
Penelitian ini bertujuan untuk mendeskripsikan pemerolehan fonologi berupa pemerolehan vokal, konsonan, dan diftong. Metode dalam penelitian ini adalah metode kualitatif dengan pendekatan studi kasus yang diperoleh seorang laki-laki berusia 4 tahun. Pada penelitian ini ditemukan bahwa IHA (kepanjangannya) telah memperoleh fonem vokal lengkap di usia 4 (empat) tahun dan sebagian besar bunyi konsonan juga telah diperoleh. Bunyi vokal rangkap atau diftong juga telah ia kuasai. Sementara bunyi frikatif [f], bunyi getar [r] belum dikuasainya sampai usia 4 (empat) tahun. Uniknya, IHA memiliki pola tersendiri jika menemukan konsonan /l/ dan konsonan /r/ yang terletak pada akhir kata. IHA akan menggantinya dengan fonem //y//. Ini terjadi karena speech motor yang IHA miliki belum lengkap atau belum berkembang dengan sempurna.
\end{abstract}

Kata kunci: pemeroleh fonologi vokal; konsonan; bahasa

Coresponden Author

Email: ririamanda.fit@gmail.com Artikel dengan akses terbuka dibawah lisensi 


\section{Pendahuluan}

Bahasa adalah alat komunikasi yang terorganisasi dalam bentuk satuan-satuan, seperti kata, kelompok kata, klausa, dan kalimat yang diungkapkan baik secara lisan maupun tulis (Wiratno \& Santosa, 2014).

Bahasa adalah bunyi ujar yang digunakan sebagai alat komunikasi. Bahasa dijadikan sebagai alat komunikasi antar masyarakat, yang berupa bunyi, suara, tanda/isyarat atau lambang yang dikeluarkan oleh manusia untuk menyampaikan isi hatinya kepada manusia yang lain (Markub, 2015). Setiap orang mengalami proses pemerolehan bahasa yang berbeda-beda. Bahasa pertama seseorang adalah bahasa ibu yang didapat sang anak dari lingkungannya. Pemerolehan bahasa sebagai proses awal dari penguasaan bahasa yang dilakukan oleh anak dilakukan secara natural pada waktu dia belajar bahasa ibunya. Proses ini berlangsung di dalam otak kanak-kanak ketika dia memperoleh bahasa pertamanya atau bahasa ibunya. Pemerolehan bahasa biasanya dibedakan dari pembelajaran bahasa. Pembelajaran bahasa selalu berkaitan dengan proses-proses yang terjadi pada waktu seorang kanak-kanak mempelajari bahasa kedua setelah dia memperoleh bahasa pertamanya. Orang tua diminta untuk mengerti perkembangan bahasa pada anak dan mengerti bahwa karakter pengaruh sosial sangat penting untuk pendidikan si anak. Jadi, pemerolehan bahasa berkenaan dengan bahasa pertama, sedangkan pembelajaran bahasa berkenaan dengan bahasa kedua (Dardjowidjojo, 2012), ( Kusuma, 2016), (Tarigan, 2009), (Molai, 2019).

Menurut (Tussolekha, 2015) seorang anak yang memiliki status normal pertumbuhan pikirannya akan mempelajari bahasa pertama yaitu bahasa ibunya dalam tahun-tahun pertama dalam hidupnya. Proses ini terjadi hingga kira-kira umur 5 (lima) tahun. Sedangkan perkembangan bahasa memiiki konsep tentang kemampuan anak untuk memberikan respon terhadap suara, mengikuti perintah, berbicara sopan perintah dan berbicara sopan (Safitri, 2017).

Seseorang akan melewati beberapa tahapan saat memperoleh bahasa pertamanya. Meskipun urutan pemunculan bunyi bersifat genetik karena perkembangan biologi manusia itu tidak sama, maka waktu munculnya suatu bunyi tidak dapat diukur dengan tahun atau bulan kalender, namun ini perhatikan (Dardjowidjojo, 2012). Hal tersebut seperti yang dikemukakan oleh Maksan (1993) yang membagi proses pemerolehan bahasa menjadi enam tahap. Membabel $(0 ; 0$ $1 ; 0)$, holofrasa $(1 ; 0-2 ; 0)$, ucapan dua kata $(2 ; 0-2 ; 6)$, permulaan tata bahasa $(2 ; 6-$ $3 ; 0)$, menjelang tata bahasa dewasa $(3 ; 0-4 ; 0)$, dan kecakapan penuh $(4 ; 0-5 ; 0)$. Fatmawati (2015) menjelaskan beberapa tahap pemerolehan bahasa yang terbagi menjadi empat tahap, yaitu tahap pralinguistik, tahap satu kata, tahap dua kata, dan tahap banyak kata.

Kajian mengenai pemerolehan bahasa mencakup empat pemerolehan umum yaitu pemerolehan fonologi, morfologi, sistaksis, dan semantik. Pemerolehan bahasa anak dimulai dari pemerolehan fonologi yaitu ilmu yang mempelajari tentang bunyi ujaran (Muslich, 2015). Kajian fonologi bertujuan untuk menemukan fonem-fonem termasuk membahas peran fonem dalam membentuk struktur suku kata (Subroto, 
2007), (Amril \& Ermanto, 2007). Menurut (Widyorini, Marlina Dwisiwi dan, Julananda Putri Sahasti, 2018). Fonologi memiliki pola yang jauh lebih bervariasi dengan adanya sistem yang biasa terlihat dalam pemerolehan fonologi anak. Hal tersebut karena beberapa anak mengembangkan pemerolehan fonologinya cukup berbeda dari target morfologi dan dari biasanya dalam berkembang fonologi. Kemampuan menganalisis fonologi serta kemampuan berujar pada setiap anak akan berbeda, tidak bergantung pada usia (Amaliah, 2017). Pemerolehan fonologi berhubungan dengan proses penyusunan suku kata yang terdiri dari vokal dan konsonan.

Sistem fonologi anak dapat dilihat melalui perkembangan saat anak mulai mengucapkan kata-kata pertamanya dalam kaidah bahasa yang baik dan penyampaian makna dengan benar. Jadi, sistem bunyi seorang anak ditandai dengan dimulainya anak berkomunikasi saat berusia sekitar satu tahun. (Eviyanti, 2008) mengatakan bahwa dalam pemerolehan fonologi setiap individu mempunyai variasi tesebut dapat berupa: 1) variasi performance, yang dilihat berdasarkan keturunan dalam bentuk pilihan yang berbeda atau kemampuan perbedaan tipe belajar sehingga menentukan perbedaan di antara anak, 2) variasi lingkungan, yaitu keadaan yang disebabkan oleh perbedaan dalam input pada anak yang berbeda, dan 3) variasi linguistik, yaitu keadaan yang timbul dari sejumlah pilihan yang berbeda pada piranti pemerolehan bahasa yang menyediakan pemerolehan terutama jenis struktur.

Penelitian bahasa anak cukup banyak dilakukan peneliti lainnya, seperti penelitian pemerolehan bahasa anak yang dilakukan oleh Prima Gusti Yanti pada anak

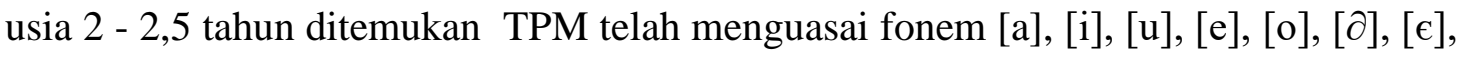
dan [O]. Fonem vokal itu dikuasainya pada usia 2 tahun 1 bulan. Vokal pertama yangdikuasainya adalah vokal [a], [i], dan [u].

Penelitian pada seorang anak berusia 2 tahun ditemukan repertoar fonetik mereka kehilangan beberapa frikatif dan semua affricates, serta /r/. Secara konsisten menggunakan pola kesalahan diidentifikasi termasuk pengurangan gugus, penghapusan konsonan akhir, berhenti, fronting, suku kata lemah, penghapusan, meluncur dan deaffrication. Temuan ini memberikan bukti awal bahwa penilaian formal langsung dari anak berusia 2 tahun (McIntosh \& Dodd, 2008).

Berdasarkan penelitian yang sudah dilakukan oleh banyak peneliti terlihat bahwa anak usia berkisar 2-5 tahun, kesulitan dalam memperoleh konsonan /r/. Selain itu, untuk anak yang memiliki orang tua yang menggunakan multibahasa ditemukan bahwa penguasaan bahasa anak menjadi dua. Untuk itu, penulis juga ingin meneliti pemerolehan fonologi pada seorang anak Melayu yang mendapat bahasa Ibu yaitu Bahasa Indonesia. Penelitian ini bertujuan untuk memaparkan pemerolehan fonologi yang meliputi pemerolehan vokal, pemerolehan konsonan, dan diftong yang diperoleh seorang anak yang berusia 4 (empat) tahun. 


\section{Metode Penelitian}

Metode penelitian pada dasarnya merupakan cara ilmiah yang digunakan untuk mendapatkan data dengan tujuan dan kegunaan tertentu (Sugiyono, 2015). Metode yang digunakan dalam penelitian ini adalah metode kualitatif dengan pendekatan studi kasus dengan dokumentasi. Dokumentasi ini berfungsi untuk menjadi bukti mengenai adanya proses pengamatan, dan melalui dokumentasi ini juga dapat menjadi suatu cara mengantisipasi adanya kekeliruan atau kesalahan dalam proses penilaian (Amelin, Ramadan, \& Gani, 2019). Melalui metode kualitatif ini akan dideskripsikan pemerolehan dan perkembangan fonologi pada seorang anak. Desain penelitian yang digunakan adalah studi kasus pada seorang anak laki-laki bernama Ilham Hafizd Arsenio (selanjutnya disingkat IHA) yang lahir pada 14 Januari 2017. Informan dalam penelitian adalah informan utama. Informan utama adalah seseorang yang memberikan keterangan utama dalam penelitian adalah Ilham Hafizd Arsenio yang saat ini berusia 4 tahun. Untuk mempermudah peneliti dalam pengumpulan data maka peneliti menggunakan instrumen pembantu berupa buku catatan, alat rekaman, dan kamera.

\section{Hasil dan Pembahasan}

\section{A. Pemerolehan Vokal dan Konsonan}

\section{Pemerolehan Vokal}

Bentuk bunyi vokal dapat dilihat jika memenuhi kriteria berikut (1) tinggi rendahnya lidah, (2) posisi lidah, (3) ketegangan lidah, dan (4) bentuk bibir (Dardjowidjojo, 2003); (Abdul Chaer, 2007). Posisi lidah bisa berbentuk vertikal atau horizontal. Secara vertikal, vokal dibedakan menjadi vokal tinggi, misalnya bunyi [i] dan [u]; vokal tengah, misalnya bunyi [e] dan [ə]; vokal rendah, misalnya bunyi [a]. Secara horisontal vokal dapat dibedakan adanya vokal depan, misalnya bunyi [i] dan [e]; vokal pusat, misalnya bunyi [ə]; dan vokal belakang, misalnya bunyi [u] dan [o].

Pemerolehan vokal menurut bentuk mulut dibedakan adanya vokal bundar dan vokal tak bundar. Berdasarkan posisi lidah dan bentuk mulut vokal dibedakan sebagai berikut [i] adalah vokal depan tinggi tak bundar, [e] adalah vokal depan tengah tak bundar, [ə] adalah vokal pusat tengah tak bundar, [o] adalah vokal belakang tengah bundar, [a] adalah vokal pusat rendah tak bundar (Abdul Chaer, 2007). Berdasarkan tahap pemerolehan bahasa oleh Maksan, usia IHA termasuk dalam tahap kecakapan penuh yaitu saat berusia 4 sampai 5 tahun. Pemerolehan vokal IHA tergambar pada tabel berikut.

Tabel 1

Pemerolehan Vokal

\begin{tabular}{cccc}
\hline Vokal & $\begin{array}{l}\text { Vokal yang } \\
\text { diucapkan }\end{array}$ & Pelesapan fonem & Pergantian fonem \\
\hline $\mathrm{a}$ & {$[\mathrm{a}]$} & - & - \\
\hline $\mathrm{i}$ & {$[\mathrm{i}]$} & - & - \\
$\mathrm{u}$ & {$[\mathrm{u}]$} & - & - \\
\hline
\end{tabular}




\begin{tabular}{cccc}
\hline Vokal & $\begin{array}{c}\text { Vokal yang } \\
\text { diucapkan }\end{array}$ & Pelesapan fonem & Pergantian fonem \\
\hline $\mathrm{e}$ & {$[\mathrm{e}]$} & - & - \\
$\mathrm{o}$ & {$[\mathrm{o}]$} & - & - \\
$\partial$ & {$[\partial]$} & - & - \\
\hline
\end{tabular}

Pemerolehan vokal yang dimiliki oleh IHA seperti yang tergambar dari tabel menjelaskan bahwa IHA telah mendapatkan semua huruf vokalnya pada usia 4 tahun. Huruf vokal ini dapat diucapkan IHA dengan fasih dan tidak terikat pada peletakan fonemnya. Seluruh vokal dapat diucapkan IHA meski huruf tersebut terletak di awal, di tengah, atau di akhir suatu kata. IHA fasih menyebutkan kata ada, dadu, ikan, ini, ulat, ke mana, bolo, obat, dan kata lain tanpa memiliki masalah. Jadi, pemerolehan vokal IHA pada usia 4 tahun telah mencapai tahap yang sempurna.

\section{Pemerolehan Konsonan}

Bunyi-bunyi konsona dibedakan berdasarkan tiga kriteria, yaitu posisi pita suara, tempat artikulasi, dan cara artikulasi. Tempat artikulasi tidak lain daripada alat ucap yang digunakan dalam pembentukan bunyi itu.

Berdasarkan tempat artikulasinya kita mengenal antara lain konsonan: Bilabial, yaitu bunyi [p], [m], dan [b]. Labiodental, yaitu bunyi [f] dan [v]. Laminoalveolar, yaitu bunyi $[\mathrm{t}]$ dan [d]. Dorsovelar, yaitu bunyi $[\mathrm{k}]$ dan $[\mathrm{g}]$.

Berdasarkan cara artikulasinya, dapat dibedakan adanya konsonan Hambai, yakni bunyi [p, b, t, d, k, g]. Geseran, misalnya bunyi [f, s, dan z]. Paduan, yakni bunyi [c] dan [ j ]. Sengauan atau nasal, misalnya bunyi [m], [n], dan [y]. Getar atau trill, contohnya konsonan [r]. Sampingan atau lateral, contohnya konsonan [1]. Hampiran atau aproksiman atau sering juga disebut semi vokal. Misalnya konsonan [w] dan [y] (Abdul Chaer, 2012).

Pada usia 4 tahun yang disebut tahap kecakapan penuh, pemerolehan konsonan pada IHA tergambar pada tabel berikut.

Tabel 2

Pemerolehan Konsonan

\begin{tabular}{cccc}
\hline Huruf & $\begin{array}{c}\text { Huruf yang } \\
\text { diucapkan }\end{array}$ & $\begin{array}{c}\text { Pelesapan } \\
\text { fonem }\end{array}$ & Pergantian fonem \\
\hline $\mathrm{b}$ & {$[\mathrm{be}]$} & - & - \\
\hline $\mathrm{c}$ & {$[\mathrm{ce}]$} & - & - \\
\hline $\mathrm{d}$ & {$[\mathrm{de}]$} & - & - \\
\hline $\mathrm{f}$ & {$[\mathrm{esh}]$} & - & $/ \mathrm{f} / \mathrm{menjadi} / \mathrm{s} / \mathrm{dan} / \mathrm{h} /$ \\
\hline $\mathrm{g}$ & {$[\mathrm{ge}]$} & - & - \\
\hline $\mathrm{h}$ & {$[\mathrm{A}]$} & $/ \mathrm{h} /$ & - \\
\hline $\mathrm{j}$ & {$[\mathrm{je}]$} & - & - \\
$\mathrm{k}$ & {$[\mathrm{ka}]$} & - & - \\
$\mathrm{l}$ & {$[\mathrm{eng}]$} & - & $/ \mathrm{l} / \mathrm{menjadi} / \mathrm{g} /$ \\
\hline $\mathrm{m}$ & {$[\mathrm{em}]$} & - & - \\
$\mathrm{n}$ & {$[\mathrm{en}]$} & - & - \\
$\mathrm{p}$ & {$[\mathrm{pe}]$} & - & - \\
\hline
\end{tabular}




\begin{tabular}{cccc}
\hline Huruf & $\begin{array}{c}\text { Huruf yang } \\
\text { diucapkan }\end{array}$ & $\begin{array}{c}\text { Pelesapan } \\
\text { fonem }\end{array}$ & Pergantian fonem \\
\hline $\mathrm{q}$ & - & - & - \\
$\mathrm{r}$ & {$[\mathrm{eg}]$} & $/ \mathrm{r} /$ & $/ \mathrm{r} /$ menjadi $/ \mathrm{g} /$ \\
$\mathrm{s}$ & {$[\mathrm{sh}]$} & - & $/ \mathrm{s} /$ menjadi $/ \mathrm{s} / \mathrm{dan} / \mathrm{h} /$ \\
$\mathrm{t}$ & {$[\mathrm{te}]$} & - & - \\
$\mathrm{v}$ & {$[\mathrm{pe}]$} & $/ \mathrm{v} /$ & $/ \mathrm{v} /$ mejadi $/ \mathrm{p} /$ \\
$\mathrm{w}$ & {$[\mathrm{we}]$} & - & - \\
$\mathrm{x}$ & {$[\mathrm{ek}]$} & $/ \mathrm{s} /$ & - \\
$\mathrm{y}$ & {$[\mathrm{ye}]$} & - & - \\
$\mathrm{z}$ & {$[$ jet] } & $/ \mathrm{z} /$ & $/ \mathrm{z} /$ menjadi $/ \mathrm{j} /$ \\
\hline
\end{tabular}

Dari 21 konsonan dalam bahasa Indonesia, IHA mendapatkan hampir semua konsonan. Meskipun pada beberapa konsonan, IHA mengganti fonem yang ia ucapkan sesuai kemampuannya, pemerolehan konsonan IHA hampir mendekati sempurna. Akan tetapi, untuk fonem /q/, IHA mengaku sulit mengatakannya dan memilih untuk tidak menggunakan fonem tersebut. Selain itu pada fonem /f/, /l/, /r, /s/, /v/, /z/ IHA yang belum memiliki kemampuan sempurna mengganti pengucapannya sesuai dengan kemampuan yang ia miliki. Pada fonem /h/, dan /x/, IHA melepaskn fonemnya.

Berdasarkan pemerolehan konsonan pada IHA, ditemukan beberapa keunikan. Hal ini ditemukan pada pemerolehan fonem /l/ dan /r/. IHA cenderung mengubah kedua fonem tersebut jika disebutkan dalam kata dengan pola dan susunan yang sama. Pemroleha unik ini dilihat dari pemerolehan konsonan berdasarkan letaknya di dalam sebuah kata.

Tabel 2

Pemerolehan Konsonan Unik

\begin{tabular}{cccc}
\hline Fonem & di awal & di tengah & di akhir \\
\hline $\mathbf{r}$ & - & - & - \\
$\mathbf{l}$ & $\sqrt{ }$ & $\sqrt{ }$ & - \\
\hline
\end{tabular}

IHA belum mendapat pemerolehan konsonan /r/ meski letaknya di awal, di tengah, maupun di akhir. Akan tetapi, untuk fonem /1/, IHA belum memperoleh konsonannya jika fonem /l/ terletak di akhir kata. Keunikan lain pada kedua pemerolehan ini dilhat dari kaa-kata yang diucapkan IHA. Kata-kata dengan susunan unik milik IHA dapat diihat pada tabel berikut.

Tabel 3

Susunan Perubahan pada Kata yang Memiliki Fonem /// yang Berada di Tengah

\begin{tabular}{llll}
\hline Kata & $\begin{array}{l}\text { Kata yang } \\
\text { diucapkan }\end{array}$ & Pelesapan fonem & Pergantian fonem \\
\hline kelapa & {$[$ kapa] } & $/ \mathrm{e} /, / \mathrm{l} /$ & - \\
selamat & {$[$ camat $]$} & $/ \mathrm{e} /, / \mathrm{l} /$ & - \\
\hline
\end{tabular}




\begin{tabular}{llll}
\hline Kata & $\begin{array}{l}\text { Kata yang } \\
\text { diucapkan }\end{array}$ & Pelesapan fonem & Pergantian fonem \\
\hline selatan & {$[$ catan] } & $/ \mathrm{e} /, / \mathrm{l} /$ & - \\
belakang & {$[$ bakang] } & $/ \mathrm{e} /, / / /$ & - \\
& & & \\
\hline
\end{tabular}

Keunikan yang IHA miliki adalah berubahnya susunan pengucapan suatu kata dengan pola yang sama. Seperti yang terlihat pada Tabel 2.2, IHA telah memperoleh konsonan /1/ meski berada di tengah kata. Seperti pada kata lalat atau lilit. Akan tetapi, jika fonem /1/ tersebut terletak pada tengah kata dalam kata yang terdiri dari tiga suku kata, IHA cenderung mengilangkan bunyi beberapa fonem.

Contohnya pada kata kelapa, IHA menyebutkannya dengan kapa; belakang disebutkan menjadi bakang. Dengan demikian pola pelesapan fonem yang miliki IHA tergambar seperti pola berikut ini.

Kata yang diucapkan $=\mathrm{KD}-\mathrm{f} 1, \mathrm{f} 2$

Kata yang diucapkan $=\mathrm{K} 1+\mathrm{f} 3$ dan seterusnya

Kata yang diucapkan $=$ Kelapa $-/ \mathrm{e} /, / 1 /$

$$
\begin{aligned}
& =/ \mathrm{k} /+/ \mathrm{a} /, / \mathrm{p} /, / \mathrm{a} / \\
& =[\mathrm{kapa}]
\end{aligned}
$$

Pola ini berlaku untuk semua kata yang memiliki fonem /1/ yang berada di tengah dan terdiri dari tiga suku kata.

Tabel 4

Susunan Perubahan pada Kata yang Memiliki Fonem /// yang Berada di Akhir

\begin{tabular}{llll}
\hline Kata & Kata yang diucapkan & Pelesapan fonem & Pergantian fonem \\
\hline kail & {$[$ kain] } & $/ \mathrm{l} /$ & $/ 1 /$ menjadi $/ \mathrm{y} /$ \\
kuil & {$[$ kuin] } & $/ \mathrm{l} /$ & $/ 1 /$ menjadi $/ \mathrm{y} /$ \\
mail & {$[$ main] } & $/ 1 /$ & $/ 1 /$ menjadi $/ \mathrm{y} /$ \\
kutil & {$[$ kutin] } & $/ \mathrm{l} /$ & $/ 1 /$ menjadi $/ \mathrm{y} /$ \\
& & & \\
\hline
\end{tabular}

Pada fonem /1/ yang terletak di akhir kata, IHA memang belum mendapatkannya. IHA cenderung membuat pola yang sama jika mengatakan kata-kata dengan fonem /1/ di akhir kata. Seperti contoh yang terdapat pada Tabel 2.4. Pola pelesapan dan pergantian fonem dengan kata berfonem /1/ digambarkan sebagai berikut.

Kata yang diucapkan $=\mathrm{KD}-\left(\mathrm{f}_{\text {akhir }}\right.$ diganti menjadi $\left./ \mathrm{y} /\right)$

$$
\begin{aligned}
& =\text { kail }-(/ 1 / \text { diganti menjadi } / \mathrm{y} /) \\
& =[\text { kain }]
\end{aligned}
$$

Pola ini berlaku untuk semua kata yang memiliki fonem /1/ yang berada di akhir kata. 
Tabel 5

Susunan Perubahan pada Kata yang Memiliki Fonem /r/ yang Berada di Akhir

\begin{tabular}{cccc}
\hline Kata & Kata yang diucapkan & Pelesapan fonem & Pergantian fonem \\
\hline kamar & {$[$ kaman] } & $/ \mathrm{r} /$ & $/ \mathrm{r} /$ menjadi $/ \mathrm{y} /$ \\
lapar & {$[$ lapan] } & $/ \mathrm{r} /$ & $/ \mathrm{r} /$ menjadi $/ \mathrm{y} /$ \\
air & {$[$ ain] } & $/ \mathrm{r} /$ & $/ \mathrm{r} /$ menjadi $/ \mathrm{y} /$ \\
hampir & {$[$ hampin] } & $/ \mathrm{r} /$ & $/ \mathrm{r} /$ menjadi $/ \mathrm{y} /$ \\
\hline motor & {$[$ moton] } & $/ \mathrm{r} /$ & $/ \mathrm{r} /$ menjadi $/ \mathrm{y} /$ \\
bor & {$[$ bon] } & $/ \mathrm{r} /$ & $/ \mathrm{r} /$ menjadi $/ \mathrm{y} /$ \\
kapur & {$[$ kapun] } & $/ \mathrm{r} /$ & $/ \mathrm{r} /$ menjadi $/ \mathrm{n} /$ \\
hancur & {$[$ kapuy] } & $/ \mathrm{r} /$ & $/ \mathrm{r} /$ menjadi $/ \mathrm{y} /$ \\
per & {$[$ pen] } & $/ \mathrm{r} /$ & $/ \mathrm{r} /$ menjadi $/ \mathrm{y} /$ \\
senter & {$[$ senten] } & $/ \mathrm{r} /$ & $/ \mathrm{r} /$ menjadi $/ \mathrm{y} /$ \\
& & & \\
\hline
\end{tabular}

Pada fonem $/ \mathrm{r} /$ yang terletak di akhir kata, IHA memang belum mendapatkannya. IHA cenderung membuat pola yang sama jika mengatakan kata-kata dengan fonem /r/ di akhir kata. Seperti contoh yang terdapat pada Tabel 2.5. Pola pelesapan dan pergantian fonem dengan kata berfonem $/ \mathrm{r} /$ digambarkan sebagai berikut.

Kata yang diucapkan $=\mathrm{KD}-\left(\mathrm{f}_{\text {akhir }}\right.$ diganti menjadi $\left./ \mathrm{h} /\right)$

$$
\begin{aligned}
& =\text { kapur }-(/ \mathrm{r} / \text { diganti menjadi } / \mathrm{y} /) \\
& =[\text { kapun }]
\end{aligned}
$$

Pola ini berlaku untuk semua kata yang memiliki fonem /r/ yang berada di akhir kata dengan huruf vokal yang berbeda-beda. Pada dasarnya Hanya saja untuk anak yang tergolong-pemberontak, atau negativistiknya kuat, umumnya enggan dikoreksi. Sebaiknya kita tidak memaksa meski tetap memberi tahu yang benar dengan mengulang kata yang dia ucapkan (Devianty, 2016). Untuk itu, agar anak menjadi fasih berbicara sesuai kaidah, perlu kerja keras orang tua dan lingkungan sekitar untuk terus mengoreksi ucapan anak tersebut. Pelafalan tuturan anak yang tidak sempurna, misalnya dalam pelafalan terdapat pelesapan fonem dan perubahan fonem. Pelesapan dan perubahan fonem terjadi karena anak-anak belum dapat melafalkan fonem-fonem tertentu (Maharany, 2016).

\section{B. Pemerolehan Diftong atau Vokal Rangkap}

\section{Diftong atau Vokal Rangkap}

Diftong atau vokal rangkap adalah bunyi saat posisi lidah ketika memproduksi bunyi ini pada bagian awalnya dan bagian akhirnya tidak sama. Ketidaksamaan itu menyangkut tinggi rendahnya lidah, bagian lidah yang bergerak serta strikturnya. Namun yang dihasilkan bukan dua buah bunyi, melainkan hanya sebuah bunyi karena berada dalam satu silabel. Contoh diftong dalam bahasa Indonesia adalah [au] seperti terdapat pada kata kerbau dan harimau. Contoh lain, bunyi [ai] seperti terdapat pada kata cukai dan landai. 
Apabila dua buah vokal berurutan, namun yang pertama terletak pada suku kata yang berlainan dari yang kedua, maka di situ tidak ada diftong. Jadi vokal [au] dan [ai] pada kata seperti bau dan lain bukan diftong (Abdul Chaer, 2012).

Pemerolehan diftong atau vokal rangkap yang terjadi pada IHA telah mencapai tahap yang baik karena kemampuannya dalam mengucapkan diftong. Pemerolehan diftong dapat dilihat pada tabel berikut.

Tabel 6

Pemerolehan Diftong

\begin{tabular}{llll}
\hline Kata & Kata yang diucapkan & Pelesapan fonem & Pergantian fonem \\
\hline pantai & {$\left[\right.$ panta $\left.^{\mathrm{y}}\right]$} & - & - \\
pulau & {$\left[\mathrm{pulau}^{2}\right.$} & - & - \\
sampai & {$\left[\mathrm{sampa}^{\mathrm{y}}\right]$} & - & - \\
amboi & {$\left[\right.$ ambo $\left.^{\mathrm{y}}\right]$} & - & - \\
survei & {$\left[\right.$ cuvei $^{2}$} & $/ \mathrm{r} /$ & $/ \mathrm{s} /$ menjadi /c/ \\
& & & \\
\hline
\end{tabular}

IHA mulai mendapatkan diftong mulai usia tiga tahun. Memasuki usia ke empat, IHA tergolong mahir mengucapkan diftong tanpa masalah. Hanya saja, pengucapan diftong dengan kata-kata yang memiliki konsonan /r/, IHA akan menggantinya sesuai dengan kemampuan yang ia miliki.

\section{Kesimpulan}

Sampai usia 4 (empat) tahun, IHA telah memperoleh sebagian besar fonem dalam Bahasa Indonesia. IHA telah memperoleh semua vokal, semua diftong, dan sebagian besar konsonan. Untuk konsonan yang belum sama sekali dapat diucapkan oleh IHA adalah fonem /q/. Sedangkan untuk konsonan f, l, r, s, v, x, dan z, IHA cenderung menggantinya.

Ini terjadi karena gangguan fonologis bisa dikarenakan faktor usia yang mengakibatkan alat bicara atau otot-otot yang digunakan untuk berbicara (speech motor) belum lengkap atau belum berkembang sempurna; dari susunan gigi geligi, bentuk rahang, sampai lidah yang mungkin masih kaku. Hal ini sejalan dengan yang mengatakan bahwa selain menggunakan struktur bahasa yang masih kacau, anak-anak juga cenderung masih menguasai keterbatasan dalam kosa kata dan pelafalan fonemnya secara tepat. 


\section{BIBLIOGRAFI}

Amaliah, Mia Nur. (2017). Pemerolehan Kompetensi Fonologis Dan Gangguan Pemroduksian Ujaran Pada Anak Berusia 3 Sampai 4 Tahun. Caraka: Jurnal Pendidikan Bahasa Dan Sastra Indonesia Serta Bahasa Daerah, 6(2), 47.

Amelin, Risanti, Ramadan, Syahrul, \& Gani, Erizal. (2019). Memahami bahasa anak usia 14 bulan melalui unsur "non-linguistik." Jurnal Obsesi: Jurnal Pendidikan Anak Usia Dini, 3(1), 146-152.

Amril \& Ermanto. (2007). Fonologi Bahasa Indonesia. Padang: UNP Press.

Chaer, A. (2003). linguistik umum. Jakarta: Jakarta: PT. Rineka Cipta.

Chaer, Abdul. (2007). Linguistik umum. Penerbit Rineka Cipta.

Dardjowidjojo, Soenjono. (2012). Psikolinguistik: Pengantar pemahaman bahasa manusia. Yogyakarta: Yayasan Pustaka Obor Indonesia.

Dardjowidjojo, Soenjono. (2003). Psikolinguistik: Pengantar pemahaman bahasa manusia. Yayasan Pustaka Obor Indonesia.

Devianty, Rina. (2016). Pemerolehan bahasa dan gangguan bahasa pada anak usia batita. Jurnal Raudhah, 4(1).

Eviyanti, Evi. (2008). Pemerolehan fonologi pada anak umur 2; 3. Jurnal Bahas, 17(01).

Fatmawati, Endang. (2015). Technology Acceptance model (TAM) untuk menganalisis penerimaan terhadap sistem informasi di perpustakaanM Informasi Perpustakaan. Iqra: Jurnal Perpustakaan Dan Informasi, 9(1), 196942.

Hastuti, Sri Kurnia. (2018). Analisis pemerolehan bahasa pertama (bahasa melayu) pada anak usia 3 tahun. Jurnal Pena Indonesia, 4(1), 106-114.

Maharany, Andi Firdha. (2016). Gejala fonologis bahasa indonesia pada anak usia 3-4 tahun di PAUD Permata Hati kota Kendari. Jurnal Bastra (Bahasa Dan Sastra), 2(1).

Markub, Markub. (2015). Perubahan Bunyi Fonem pada Kosakata Bahasa Indonesia dalam Kosakata Bahasa Melayu Thailand. Prosiding Seminar Internasional Pendidikan Bahasa Dan Sastra Indonesia.

McIntosh, Beth, \& Dodd, Barbara J. (2008). Two-year-olds' phonological acquisition: Normative data. International Journal of Speech-Language Pathology, 10(6), 460-469.

Molai, Tahereh Nasabpour. (2019). Factors Affecting Language Development of Children. Sciences, 6(1), 37-48. 
Riri Amanda Fitriana

Muslich, Mansur. (2015). Fonologi Bahasa Indonesia. Jakarta: Bumi Aksara.

Safitri, Yenny. (2017). Faktor-faktor yang berhubungan dengan perkembangan bahasa balita di UPTD kesehatan Baserah tahun 2016. Jurnal Obsesi: Jurnal Pendidikan Anak Usia Dini, 1(2), 148-155.

Subroto, Edi. (2007). Pengantar Metode Penelitian Linguistik Struktural. Surakarta: UPT Penerbitan dan Pencetakan UNS. UNS Press.

Sugiyono. (2015). Metode Penelitian Kuantitatif Kualitatif dan R\&D. Bandung: Alfabeta.

Tarigan, Henry Guntur. (2009). Psikolinguistik. Bandung: Angkasa.

Tussolekha, Rohmah. (2015). Mekanisme pemerolehan bahasa pada anak usia satu dan lima tahun. Jurnal Pesona, 1(2).

Widyorini, Marlina Dwisiwi dan, Julananda Putri Sahasti, dan Sumarlam. (2018). Pemerolehan Bahasa Pada Anak Usia 2-3 Tahun melalui Metode Bernyanyi di Paud Nur Insani Piyaman. Wonosari,Gunungkidul: .Medan Makna. XVI(2).

Wiratno, Tri, \& Santosa, Riyadi. (2014). Bahasa, Fungsi Bahasa, dan Konteks Sosial. Modul Pengantar Linguistik Umum, 1-19. 